\begin{tabular}{|c|l|}
\hline Title & Growth and photosynthetic response of Fagus crenata seedlings to ozone and/or elevated carbon dioxide \\
\hline Author(s) & Watanabe, Makoto; U memoto-Y amaguchi, Michiko; Koike, Takay oshi; I zuta, Takeshi \\
\hline Citation & $\begin{array}{l}\text { Landscape and Ecological Engineering, 6(2), 181-190 } \\
\text { https://doi.org/L0.1007/311355-009-0095-2 }\end{array}$ \\
\hline Issue Date & 2010-07 \\
\hline Doc URL & http://hdl.handle.net/2115/43279 \\
\hline Rights & The final publication is available at www.springerlink.com \\
\hline Type & article (author version) \\
\hline File Information & LEE6-2_181-190.pdf \\
\hline
\end{tabular}

Instructions for use 


\title{
Title
}

Growth and photosynthetic response of Fagus crenata seedlings to ozone and/or elevated carbon dioxide

\section{Names and addresses of the authors}

Makoto Watanabe ${ }^{1,2}$, Michiko Umemoto-Yamaguchi ${ }^{3}$, Takayoshi Koike ${ }^{2,3}$, Takeshi Izuta $^{4^{*}}$

\author{
${ }^{1}$ JSPS Research Fellow \\ ${ }^{2}$ Silviculture and Forrest Ecological Studies, Hokkaido University, Sapporo \\ 060-8589, Japan \\ ${ }^{3}$ Graduate School of Agriculture, Tokyo University of Agriculture and Technology, \\ Fuchu, Tokyo 183-8509, Japan \\ ${ }^{4}$ Institute of Symbiotic Science and Technology, Tokyo University of Agriculture \\ and Technology, Fuchu, Tokyo 183-8509, Japan.
}

\section{Corresponding author}

Takeshi Izuta

Tel. \& Fax.: +81-42-367-5728, E-mail: izuta@cc.tuat.ac.jp

Fuchu, Tokyo 183-8509, Japan.

\section{Erratum}

The original version of this article contained errors unfortunately, 1 Prof. Takeshi Izuta should be indicated as the corresponding author. 2 The unit for the vertical axis in Fig. 1 should be $\left(\mathrm{cm}^{2}\right)$, not $\left(\mathrm{cm}^{-2}\right)$. We sincerely apologize for the errors. 


\section{Abstract}

We investigated the effects of ozone $\left(\mathrm{O}_{3}\right)$ and/or elevated $\mathrm{CO}_{2}$ concentration $\left(\left[\mathrm{CO}_{2}\right]\right)$ on the growth and photosynthetic traits of Fagus crenata seedlings. Two-year-old seedlings were grown in four experimental treatments comprising two $\mathrm{O}_{3}$ treatments (charcoal-filtered air and $100 \mathrm{nmol} \mathrm{mol}^{-1} \mathrm{O}_{3} ; 6 \mathrm{~h} /$ day, 3 days/week) in combination with two $\mathrm{CO}_{2}$ treatments (350 and $700 \mu \mathrm{mol} \mathrm{mol}{ }^{-1}$ ) for 18 weeks in environmental control growth chambers. The four treatments were designated as control, elevated $\mathrm{O}_{3}$, elevated $\mathrm{CO}_{2}$, and elevated $\mathrm{CO}_{2}+\mathrm{O}_{3}$. Dry matter growth of the seedlings was greater in elevated $\mathrm{CO}_{2}+\mathrm{O}_{3}$ than in elevated $\mathrm{CO}_{2}$. In elevated $\mathrm{CO}_{2}+\mathrm{O}_{3}$, a marked increase of second-flush leaves, considered a compensative response to $\mathrm{O}_{3}$, was observed. The net photosynthetic rate of first-flush leaves in elevated $\mathrm{CO}_{2}+\mathrm{O}_{3}$ increased earlier and was maintained for a longer period of time than that in elevated $\mathrm{CO}_{2}$. Because emergence of second-flush leaves of F. crenata is greatly affected by the amount of assimilation products of first-flush leaves in current year, we consider that an early increase in the net photosynthetic rate of first-flush leaves contributed to the marked increase in second-flush leaf emergence under elevated $\mathrm{CO}_{2}+\mathrm{O}_{3}$. These results imply that we must account for changes in compensative capacity with respect not only to morphological traits but also phenological traits and physiological functions such as photosynthesis for evaluating $\mathrm{O}_{3}$ effects on F. crenata under elevated $\left[\mathrm{CO}_{2}\right]$.

\section{Key words}

Compensative response, second-flush, Combined effects, Ecophysiological response, Air pollution 


\section{Introduction}

Fagus crenata is one of the most common and widely distributed deciduous broad-leaved tree species in the cool temperate forests of Japan (Nakashizuka and Iida, 1995; Peters 1997). F. crenata is an important tree species in Japan because its forests help to conserve forest soil and to maintain biodiversity, and is planted for afforestation as well as for ceremonial plantations (e.g., Murai et al. 1991; Nakashizuka 2004; Terazawa and Koyama 2008). Natural forests of F. crenata on the Shirakami Mountains (northeast Japan) were registered by UNESCO as a World Natural Heritage sites in December 1993. However, forest decline and dieback of $F$. crenata have been markedly observed in several mountainous areas in Japan since the late 1980s, including the Tanzawa Mountains in the Kanto region and Tateyama in the Hokuriku region. Several researchers have implicated ozone $\left(\mathrm{O}_{3}\right)$ as an important factor in these symptoms of decline (Kume et al., 2009; Takeda and Aihara, 2007).

Tropospheric $\mathrm{O}_{3}$ is recognized as a widespread phytotoxic gaseous air pollutant, and its concentrations have been increasing in the Northern Hemisphere (ADORC 2006; Akimoto 2003). In Japan, the annual average daytime concentration of photochemical oxidant, of which the main component is $\mathrm{O}_{3}$, increased at a rate of about $0.33 \mathrm{nmol} \mathrm{mol}^{-1}$ year $^{-1}$ from 1985 to 1999 and was about $31 \mathrm{nmol} \mathrm{mol}^{-1}$ as an average from 1999 to 2002 (ADORC 2006; Ohara and Sakata 2003). Furthermore, relatively high $\mathrm{O}_{3}$ concentrations $\left(\left[\mathrm{O}_{3}\right]\right)$ above 100 nmol mol${ }^{-1}$ have been frequently detected not only in the suburbs of metropolitan areas such as Tokyo and Osaka, but also in several mountainous areas (Network Center for EANET 2007; Takeda and Aihara 2007; Wakamatsu et al. 1998; 
Yoshikado 2004).

The impact of $\mathrm{O}_{3}$ on tree species is greatly affected by soil and/or atmospheric conditions (Matsumura et al. 2005; Matyssek and Sandermann 2003; Pearson and Mansfield 1993; Watanabe et al. 2005; Yamaguchi et al. 2007). Whether recent increasing $\mathrm{CO}_{2}$ concentration $\left(\left[\mathrm{CO}_{2}\right]\right)$ can ameliorate the adverse effect of $\mathrm{O}_{3}$ on tree species is currently a subject of debate (Karnosky et al. 2001). Although no evidences of amelioration of $\mathrm{O}_{3}$ impact by elevated $\left[\mathrm{CO}_{2}\right]$ have been reported (Barns et al. 1995; Kull et al. 1996), many studies have demonstrated ameliorating effects by elevated $\left[\mathrm{CO}_{2}\right]$ with respect to $\mathrm{O}_{3}$-induced reduction in photosynthesis and growth (Grams et al. 1999; Lütz et al. 2000; Manes et al. 1998; Volin et al. 1998) Numerous experiments have indicated stomatal closure induced by elevated $\left[\mathrm{CO}_{2}\right]$ (Ainsworth and Rogers 2007; Saxe et al. 1998). Therefore, one of the most conceivable ameliorations of adverse $\mathrm{O}_{3}$ effect by elevated $\left[\mathrm{CO}_{2}\right]$ is decrease of stomatal $\mathrm{O}_{3}$ uptake in leaves because of elevated $\mathrm{CO}_{2}$-induced stomatal closure (McKee et al. 1995; Volin et al. 1996; Volin et al. 1998). On the other hand, compensatory growth of new leaves may occur to prevent the $\mathrm{O}_{3}$-induced decline of whole-plant photosynthesis even in beech, which usually emerges leaves once during one growing season (Kikuzawa 1983; Kozovits 2003; Landolt et al. 1997; Matyssek and Sandermann 2003; Pell et al. 1994). Because assimilates are needed for producing new leaves (Matyssek and Sandermann 2003; Pell et al. 1994), there is a possibility that the compensative new leaf emergence in response to $\mathrm{O}_{3}$ is stimulated under elevated $\left[\mathrm{CO}_{2}\right]$, which will increase production of assimilates in leaves. 
Paludan-Muller et al. (1999) reported a considerable variability in $\mathrm{O}_{3}$ sensitivity among Fagus sylvatica seedlings from 12 provenances. This indicates that while the studies on the combined effects of $\mathrm{O}_{3}$ and elevated $\left[\mathrm{CO}_{2}\right]$ on tree species conducted in Europe and North America provide useful information, we cannot directly apply that information to Japanese tree species. Thus, little information is available on the combined effects of $\mathrm{O}_{3}$ and elevated $\left[\mathrm{CO}_{2}\right]$ on tree species native to Japan (Matsumura et al. 2005).

Therefore, in the present study, we investigated the effects of $\mathrm{O}_{3}$ and/or elevated $\left[\mathrm{CO}_{2}\right]$ on the growth and photosynthetic traits of F. crenata seedlings in order to provide a basic understanding of these issues for conservation of F. crenata forests. Our hypothesis is that the negative impact of $\mathrm{O}_{3}$ is ameliorated under elevated $\left[\mathrm{CO}_{2}\right]$ because of elevated $\left[\mathrm{CO}_{2}\right]$-induced reduction in the $\mathrm{O}_{3}$ uptake of leaves and stimulation of compensative response to $\mathrm{O}_{3}$.

\section{Materials and methods}

\subsection{Plant material}

Two-year-old seedlings of $F$. crenata were transplanted into 2-L pots (11-cm diameter) filled with brown forest soil collected from a mixed deciduous forest at the University Forest of Tokyo University of Agricultural and Technology (Midori, Gunma Prefecture, Japan). We obtained F. crenata seedlings of the Toyama Prefecture provenance, meaning that the seedlings have traits related to survival in a heavy snow region (Koike et al. 1998; Koike and Maruyama 1998). Moreover, symptoms of $F$. crenata forest decline have been observed in this prefecture (Ishida 2004; Kume et al. 2009). All the seedlings were transferred into 
four environmental control growth chambers $\left(0.815 \times 1.200 \times 1.815 \mathrm{~m}^{3}\right.$, Koito Co. Ltd., Japan) and grown for 22 weeks (from 4 May to 7 October, 1995). The photoperiod in the chamber was $15 \mathrm{~h}$ (05:00-20:00) and the photosynthetic photon flux (PPF) at the canopy of the seedlings in the chambers was controlled at $600 \mu \mathrm{mol} \mathrm{m} \mathrm{m}^{-2} \mathrm{~s}^{-1}$. We used 14 fluorescent lamps and incandescent lamps as light sources in each chamber to simulate natural sunlight. The temperature in the growth chamber was gradually increased from $16^{\circ} \mathrm{C}$ to $22^{\circ} \mathrm{C}$ during the time period 5:00-7:00 and was gradually decreased from $22^{\circ} \mathrm{C}$ to $16^{\circ} \mathrm{C}$ from $18: 00$ to 20:00. During the periods 7:00-18:00 and 20:00-5:00, the temperature was maintained at $22^{\circ} \mathrm{C}$ and $16^{\circ} \mathrm{C}$, respectively. The relative humidity was regulated at $75 \%$. The rate of air change in the growth chambers was set at $13.6 \mathrm{~m}^{3} \mathrm{~h}^{-1}$ (i.e., the air volume was changed approximately 8 times $\left.\mathrm{h}^{-1}\right)$. Liquid fertilizer $(\mathrm{N}: \mathrm{P}: \mathrm{K}=$ 5:10:5, Hyponex Japan, Osaka, Japan) was supplied at the rate of $280 \mathrm{mg}$ of $\mathrm{N}$ $\operatorname{pot}^{-1}$ week ${ }^{-1}$.

\section{$2.2 \mathrm{CO}_{2}$ and ozone treatments}

The seedlings were grown in four factorial treatments consisting of two levels of $\left[\mathrm{CO}_{2}\right]$ and two levels of $\left[\mathrm{O}_{3}\right]$. We started the $\mathrm{CO}_{2}$ treatment on 4 May. The charcoal-filtered ambient air $\left(350 \pm 20 \mu \mathrm{mol} \mathrm{mol}^{-1} \mathrm{CO}_{2}\right)$ was introduced into the two growth chambers and $700 \mu \mathrm{mol} \mathrm{mol}^{-1} \mathrm{CO}_{2}$ was introduced into the other two chambers. Chamber $\left[\mathrm{CO}_{2}\right]$ was regulated by a control unit (MC-F20/S, Koito Co. Ltd., Japan).

The $\mathrm{O}_{3}$ treatment was started on 4 June, when the expansion of the first-flush leaves of the seedlings had completed. We conducted the exposure of 
$\mathrm{O}_{3}$ at $100 \pm 10 \mathrm{nmol} \mathrm{mol}^{-1}$ for $6 \mathrm{~h}$ (10:00-16:00) per day, 3 days per week. The $\mathrm{O}_{3}$ was generated from ambient air with an electrical discharge $\mathrm{O}_{3}$ generator (IO-1A5, Nippon Ozone Co., Ltd., Tokyo, Japan) and injected into the chambers through a water trap to remove nitrogen by-products produced by the $\mathrm{O}_{3}$ generator such as $\mathrm{N}_{2} \mathrm{O}_{5}$ (Brown and Roberts, 1988). The $\left[\mathrm{O}_{3}\right]$ in the growth chambers were continuously monitored with a UV absorption $\mathrm{O}_{3}$ analyzer (TUV-1100, Tokyo Industries inc., Tokyo, Japan). In the chambers not treated with $\mathrm{O}_{3}$, the $\left[\mathrm{O}_{3}\right]$ was below $10 \mathrm{nmol} \mathrm{mol}{ }^{-1}$.

The four treatments were designated as control $\left(350 \mu \mathrm{mol} \mathrm{mol}{ }^{-1} \mathrm{CO}_{2}+\right.$ $\left.<10 \mathrm{nmol} \mathrm{mol}^{-1} \mathrm{O}_{3}\right)$, elevated $\mathrm{O}_{3}\left(350 \mu \mathrm{mol} \mathrm{mol}{ }^{-1} \mathrm{CO}_{2}+100 \mathrm{nmol} \mathrm{mol}{ }^{-1} \mathrm{O}_{3}\right)$, elevated $\mathrm{CO}_{2}\left(700 \mu \mathrm{mol} \mathrm{mol}{ }^{-1} \mathrm{CO}_{2}+<10 \mathrm{nmol} \mathrm{mol}^{-1} \mathrm{O}_{3}\right)$, and elevated $\mathrm{CO}_{2}+\mathrm{O}_{3}$ $\left(700 \mu \mathrm{mol} \mathrm{mol}{ }^{-1} \mathrm{CO}_{2}+100 \mathrm{nmol} \mathrm{mol}{ }^{-1} \mathrm{O}_{3}\right)$. There was no $\mathrm{CO}_{2}$ or $\mathrm{O}_{3}$ replication because of the limited number of growth chambers. Therefore, all the seedlings were switched between chambers at 2-week intervals during the growth period (Dutilleul, 1993; Potvin and Tardif, 1988). To reduce position effects in the chamber (Miao et al., 1992), the position of the seedlings was randomized at the same interval as that of the chamber switching.

\subsection{Growth analysis}

On 4 June, the starting date of the $\mathrm{O}_{3}$ exposure, the two seedlings from each treatment (four seedlings from each $\mathrm{CO}_{2}$ treatment) were randomly harvested (initial sampling). On 7 October, in the 18th week after the initiation of $\mathrm{O}_{3}$ exposure (WAE), we harvested five seedlings from each treatment (final sampling). Harvested seedlings were separated into leaves, branches, stems and 
roots. Because the second-flush was observed after the sixth WAE, we separated the leaves of the second-flush and that of the first-flush. Leaf area was measured with an area meter (AAM-7, Hayashidenkoh, Tokyo, Japan). The plant organs were dried at $80^{\circ} \mathrm{C}$ for 10 days and weighed.

Since there was no significant difference in the leaf area and dry mass of the seedlings between the two $\mathrm{CO}_{2}$ treatments at the initial sampling, all values of leaf area and dry mass across the $\mathrm{CO}_{2}$ treatments were averaged as the initial values. Based on the values of leaf area and dry mass of plant organs in the initial and final samplings, we calculated the relative growth rate (RGR), net assimilation rate (NAR), leaf area ratio (LAR), specific leaf area (SLA), and leaf mass ratio (LMR) according to the following formulas (Hunt, 1978):

$$
\begin{aligned}
& \text { RGR }\left(\% \text { day }^{-1}\right)=\left[\left(\ln W D M_{2}-\ln W D M_{1}\right) /\left(t_{2}-t_{1}\right)\right] \times 100 \\
& \text { NAR }\left(\mathrm{g} \mathrm{cm}^{-2} \text { day }^{-1}\right)=\left[\left(\ln L A_{2}-\ln L A_{1}\right) \times\left(W D M_{2}-W D M_{1}\right)\right] \\
& \qquad /\left[\left(L A_{2}-L A_{1}\right) \times\left(t_{2}-t_{1}\right)\right] \\
& \text { LAR }\left(\mathrm{cm}^{2} \mathrm{~g}^{-1}\right)=\mathrm{RGR} / \mathrm{NAR} \\
& \text { SLA }\left(\mathrm{cm}^{2} \mathrm{~g}^{-1}\right)=L A_{2} / L D M_{2} \\
& \operatorname{LMR}(\%)=\left(L D M_{2} / W D M_{2}\right) \times 100
\end{aligned}
$$

where $W D M, L A$, and $L D M$ are whole-plant dry mass (g), leaf area per plant $\left(\mathrm{cm}^{2}\right)$, and leaf dry mass per plant (g), respectively. The numbers next to the abbreviations indicate the harvest timing (i.e., 1 and 2 mean initial and final samplings, respectively). Time is indicated by $t$ and $t_{2}-t_{1}$ equals 126 days. 


\subsection{Measurement of gas exchange rate}

The leaf gas exchange rate of sun leaves was measured using an assimilation chamber at one week intervals from the first WAE. We randomly selected three seedlings per treatment and then measured the gas exchange rates of the same leaves throughout the experiment.

The air temperature in the assimilation chamber was maintained at $25 \pm$ $0.5^{\circ} \mathrm{C}$. The light was supplied from a cold lighting system (PICL-NEX twin, Nippon P.I., Tokyo, Japan), and the PPF at the leaf surface was maintained at 600 $\mu \mathrm{mol} \mathrm{m} \mathrm{m}^{-2} \mathrm{~s}^{-1}$. The $\left[\mathrm{CO}_{2}\right]$ and air humidity were measured with an infrared gas analyzer (IR 59-07, Yokogawa, Tokyo, Japan) and a humidity sensor (HUP35A, Vaisala, Helsinki, Finland), respectively. To obtain the intercellular $\left[\mathrm{CO}_{2}\right]$ $\left(C_{\mathrm{i}}\right)$-response curve of the net photosynthetic rate $(A)$, i.e. the $A / C_{\mathrm{i}}$ curve, the $A$ was determined for $\left[\mathrm{CO}_{2}\right]$ in the chamber at $10,100,350,700$, and $1400 \mu \mathrm{mol}$ $\mathrm{mol}^{-1}$.

We determined the $A$ and stomatal conductance at the growth $\left[\mathrm{CO}_{2}\right]$ ( $A_{\text {growth }}$ and $G_{\mathrm{s}}$, respectively), i.e., $350 \mu \mathrm{mol} \mathrm{mol}{ }^{-1}$ in the control and elevated $\mathrm{O}_{3}$ treatments and $700 \mu \mathrm{mol} \mathrm{mol}{ }^{-1}$ in the elevated $\mathrm{CO}_{2}$ and elevated $\mathrm{CO}_{2}+\mathrm{O}_{3}$ treatments. The carboxylation efficiency (CE) of photosynthesis was determined as the initial slope of the linear portion of the $A / C_{\mathrm{i}}$ curve. The $A$ at $1400 \mu \mathrm{mol}$ $\mathrm{mol}^{-1} \mathrm{CO}_{2}$ was regarded as the maximum net photosynthetic rate at saturated $\left[\mathrm{CO}_{2}\right]\left(A_{\max }\right)$.

\subsection{Statisitical analysis}

Statistical analyses were performed with the SPSS software (SPSS, Inc, 
Chicago, IL, USA). Two-way analysis of variance (two-way ANOVA) was used to test the effects the of elevated $\mathrm{CO}_{2}$ and $\mathrm{O}_{3}$ treatments. When a significant interaction between elevated $\mathrm{CO}_{2}$ and $\mathrm{O}_{3}$ treatments was detected, Duncan's new multiple range test was performed to identify significant differences among the four treatments.

\section{Results}

\subsection{Growth of seedlings}

Little difference in leaf area, dry mass of plant organs, or the ratio of above-ground dry mass to below-ground dry mass (T/R ratio) was found between control and elevated $\mathrm{O}_{3}$ treatments (Fig. 1; Table 1). However, the dry mass of second-flush leaves tended to increase. In the elevated $\mathrm{CO}_{2}$ treatment, dry mass was increased as compared to that in the control treatment (Table 1). Significant interaction between $\mathrm{O}_{3}$ and $\mathrm{CO}_{2}$ was detected for the dry mass of second-flush leaves, branches, stems, coarse roots, and whole-plant and for the leaf area of second-flush leaves. Although the dry mass and leaf area of second-flush leaves of seedlings grown under a $\left[\mathrm{CO}_{2}\right]$ of $350 \mu \mathrm{mol} \mathrm{mol}{ }^{-1}$ were not significantly changed by exposure to $\mathrm{O}_{3}$, those grown under a $\left[\mathrm{CO}_{2}\right]$ of $700 \mu \mathrm{mol} \mathrm{mol}{ }^{-1}$ were significantly increased.

The RGR under elevated $\mathrm{CO}_{2}$ and elevated $\mathrm{CO}_{2}+\mathrm{O}_{3}$ treatments was $25 \%$ and $54 \%$ higher than that under control treatment, respectively, whereas there was no change in RGR under elevated $\mathrm{O}_{3}$ treatment (Fig. 2). The NAR in the elevated $\mathrm{O}_{3}$ treatment was $20 \%$ lower than that in the control treatment, while the LAR was increased by 23\%. Although the increased NAR under elevated $\mathrm{CO}_{2}$ and 
elevated $\mathrm{CO}_{2}+\mathrm{O}_{3}$ treatments was similar (approximately 30\%), the increase of LAR was only observed under elevated $\mathrm{CO}_{2}+\mathrm{O}_{3}$ treatment.

There was no significant effect of $\mathrm{O}_{3}$ and/or elevated $\left[\mathrm{CO}_{2}\right]$ on the SLA and LMR of first-flush leaves (Fig. 3). On the other hand, the LMR of second-flush leaves was significantly increased by elevated $\left[\mathrm{CO}_{2}\right]$.

\subsection{Gas exchange rate}

Regardless of the $\mathrm{O}_{3}$ exposure, the $A_{\text {growth }}$ of seedlings grown under a $\left[\mathrm{CO}_{2}\right]$ of $700 \mu \mathrm{mol} \mathrm{mol}{ }^{-1}$ was higher than that of seedlings grown at a $\left[\mathrm{CO}_{2}\right]$ of $350 \mu \mathrm{mol} \mathrm{mol}{ }^{-1}$ (Fig. 4). The $A_{\text {growth }}$ under elevated $\mathrm{O}_{3}$ treatment was reduced after the ninth WAE as compared to that under the control treatment. The peak of $A_{\text {growth }}$ occurred at the seventh WAE under the elevated $\mathrm{CO}_{2}$ treatment, while it occurred much earlier (at the fifth WAE) under the elevated $\mathrm{CO}_{2}+\mathrm{O}_{3}$ treatment. The $G_{\mathrm{s}}$ in elevated $\mathrm{O}_{3}$ treatments was lower than that in the control treatment in most measurements. In the elevated $\mathrm{CO}_{2}$ and elevated $\mathrm{CO}_{2}+\mathrm{O}_{3}$ treatments, the level of $G_{\mathrm{s}}$ was similar but lower as compared to the control treatment. The $C E$ under the control and elevated $\mathrm{O}_{3}$ treatments was decreased beginning at about the fourth WAE, while the decrease started at the 7th and 11th WAE under elevated $\mathrm{CO}_{2}$ and elevated $\mathrm{CO}_{2}+\mathrm{O}_{3}$ treatments, respectively. There was no clear effect of $\mathrm{O}_{3}$ on the $C E$ of seedlings grown under a $\left[\mathrm{CO}_{2}\right]$ of $350 \mu \mathrm{mol} \mathrm{mol}{ }^{-1}$. An $\mathrm{O}_{3}$-induced reduction in the $A_{\max }$ was found from the 11th to the 14th and from the 5th to the 10th WAE in the 350 and $700 \mu \mathrm{mol} \mathrm{mol}{ }^{-1} \mathrm{CO}_{2}$ treatments, respectively.

Figure 5 shows the relationship between $G_{\mathrm{s}}$ and $A_{\text {growth }}$ in the first-flush leaves of F. crenata seedlings. No correlation was observed between $G_{\mathrm{s}}$ and $A_{\text {growth }}$ 
in the seedlings grown under a $\left[\mathrm{CO}_{2}\right]$ of $350 \mu \mathrm{mol} \mathrm{mol}^{-1}$ during the experimental period. In the $700 \mu \mathrm{mol} \mathrm{mol}{ }^{-1} \mathrm{CO}_{2}$ treatments, there was relatively high correlation between $G_{\mathrm{s}}$ and $A_{\text {growth }}$ until the ninth WAE. However, the correlation was not found in the 10th to the14th WAE.

\section{Discussion}

Leaves of F. crenata are usually flushed one time during the growing season because this tree is classified as a fixed-growth-type species (Kikuzawa 1983), However, subsequent leaf emergence (the second-flush) has also been found to occur under well-fertilized and good light conditions (Hashizume 1982; Hashizume and Yamamoto 1975). Therefore, the seedlings of F. crenata in the present study were grown under sufficient nutrient and light conditions.

The reduction in NAR under elevated $\mathrm{O}_{3}$ treatment (Fig. 2) indicates that the efficiency of dry matter production in the leaves was reduced by exposure to $\mathrm{O}_{3}$. The $\mathrm{O}_{3}$-induced reduction of NAR has been reported in many tree species (e.g., Izuta et al. 1996; Oksanen and Saleem 1999; Shimizu and Feng 2007). The reduction in net photosynthetic rate is considered to be one of the most important factors leading to NAR reduction in $\mathrm{O}_{3}$-exposed trees (Izuta et al. 1996; Shimizu and Feng 2007). In the present study, the $A_{\text {growth }}$ in the first-flush leaves under the elevated $\mathrm{O}_{3}$ treatment was reduced as compared to that under the control treatment after the ninth WAE (Fig. 4) contributing to NAR reduction.

The diffusion of atmospheric $\mathrm{CO}_{2}$ into leaves depends mainly on the behavior of stomata, as well as on the difference in $\left[\mathrm{CO}_{2}\right]$ between the atmosphere and the leaf interior (e.g., Lambers et al. 2008). In the present study, although no 
clear relationship between $A_{\text {growth }}$ and $G_{\mathrm{s}}$ was observed under a $\left[\mathrm{CO}_{2}\right]$ of $350 \mu \mathrm{mol}$ $\mathrm{mol}^{-1}$ (Fig. 5), the $G_{\mathrm{s}}$ in the elevated $\mathrm{O}_{3}$ treatment from the 10th to the14th WAE was lower than that in the control treatment. Thus, stomatal closure is considered to be a reason for the reduction of $A_{\text {growth }}$ in elevated $\mathrm{O}_{3}$ treatment. The $\mathrm{O}_{3}$-induced stomatal limitation of photosynthesis was also reported by Kitao et al. (2009). On the other hand, the reduction in photosynthetic activity was indicated through the analysis of $A / C_{i}$ curve. The $A_{\max }$, which reflects the RuBP regeneration rate in the Calvin cycle, depends mainly on the electron transport rate in the thylakoid membrane (Farquhar et al 1980; Sharkey 1985). The CE corresponds to the activity of $\mathrm{CO}_{2}$ fixation in the Calvin cycle and depends primarily on the activity and/or quantity of ribulose-1,5-bisphosphate carboxylase/oxygenase (Rubisco) (von Caemmerer and Farquhar 1981). In the present study, exposure to $\mathrm{O}_{3}$ reduced $A_{\max }$ in the leaves of F. crenata seedlings, while there was no clear effect of $\mathrm{O}_{3}$ on $C E$ (Fig. 4). These results strongly suggest that $\mathrm{O}_{3}$ inhibits RuBP regeneration. Although the net photosynthetic under a $\left[\mathrm{CO}_{2}\right]$ of $350 \mu \mathrm{mol} \mathrm{mol}^{-1}$ is generally restricted by the activity of carboxlation by Rubisco, there is a possibility that the reduction in the RuBP regeneration also contribute to the $\mathrm{O}_{3}$-induced reduction in $A_{\text {growth }}$. The reduction in $A_{\max }$ in F. crenata and F. sylvatica were also reported by Yonekura et al. (2001) and Lippert et al. (1996), respectively.

Because the emergence of first-flush leaves of deciduous tree species depends mainly on nutrients that reserved in the previous year (Kikuzawa 1983), the area growth and morphological traits of first-flush leaves of seedlings would not be affected by the current year $\mathrm{O}_{3}$ exposure (Figs. 1 and 3). On the other hand, the LMR of the second-flush leaves was increased by the exposure to $\mathrm{O}_{3}$ (Fig. 5), 
and this increase lead to the LAR increase. The enhancement of new leaf emergence by $\mathrm{O}_{3}$ exposure has been reported by several researchers and is considered to be one of the compensation responses to $\mathrm{O}_{3}$ (Landolt et al. 1997; Pell et al. 1994). Consequently, the $\mathrm{O}_{3}$-induced reduction in NAR of F. crenata seedlings was cancelled by the increase of LAR through the increase in LMR of the second-flush leaves.

The increase of RGR under elevated $\mathrm{CO}_{2}$ treatment was mainly due to the increase of NAR, indicating stimulation of dry matter-production efficiency in the leaves. There have been many reports on the increase of NAR by elevated [CO $\mathrm{CO}_{2}$ (e.g., Centritto et al. 1999; Pettersson and McDonald 1992). The increase of $A_{\text {growth }}$ under elevated $\mathrm{CO}_{2}$ treatment contributes to the increase of NAR. However, the stimulation of $A_{\text {growth }}$ in elevated $\mathrm{CO}_{2}$ treatment in the present study was temporary (Fig. 4). It decreased from the seventh WAE to a level of $A_{\text {growth }}$ similar to that under the control treatment. There have been many reports of acclimation of photosynthesis to elevated $\left[\mathrm{CO}_{2}\right]$ (e.g., Eguchi et al. 2008; Kitao et al. 2005). Because there was no correlation between $G_{\mathrm{s}}$ and $A_{\text {growth }}$ in the 10th to the 14th WAE (Fig. 5), the decrease of $A_{\text {growth }}$ under elevated $\mathrm{CO}_{2}$ treatment was not due to stomatal closure but to a decline of photosynthetic activity in the chloroplast. The $C E$ and $A_{\max }$ in the elevated $\mathrm{CO}_{2}$ treatment decreased from the 7th and 11th WAE, respectively (Fig. 4). Therefore, we consider that the reduction in $\mathrm{CO}_{2}$ fixation activity in the Calvin cycle was the first factor that induced reduction in the $A_{\text {growth }}$ of $F$. crenata seedlings and that the reduction in the RuBP regeneration rate was an ensuing factor (Farquhar et al 1980; Sharkey 1985; von Caemmerer and Farquhar 1981). 
Based on the single effect of $\mathrm{O}_{3}$ or elevated $\left[\mathrm{CO}_{2}\right]$ on the growth and photosynthesis of $F$. crenata seedlings, we thought that we had a plausible understanding of the combined effects of $\mathrm{O}_{3}$ and elevated $\left[\mathrm{CO}_{2}\right]$. However, a marked increase of dry matter growth was unexpectedly found in the elevated $\mathrm{CO}_{2}+\mathrm{O}_{3}$ treatment (Table 1 ). Average $G_{\mathrm{s}}$ during the $\mathrm{O}_{3}$ exposure period in elevated $\mathrm{CO}_{2}+\mathrm{O}_{3}$ treatment was $15 \%$ lower than that in elevated $\mathrm{O}_{3}$ treatment. Because stomatal conductance to $\mathrm{O}_{3}$ was considered as proportional to $G_{\text {s }}$ (Emberson et al. 2000), the decrease in leaf $\mathrm{O}_{3}$ uptake under elevated $\left[\mathrm{CO}_{2}\right]$ can be estimated as similar extent. However, the reduction in $\mathrm{O}_{3}$ uptake cannot explain the growth stimulation in elevated $\mathrm{CO}_{2}+\mathrm{O}_{3}$ treatment. Increases of both NAR and LAR contributed to the increase of RGR (Fig. 2). The increase of LAR in the elevated $\mathrm{CO}_{2}+\mathrm{O}_{3}$ treatment was mainly due to the increased emergence of second-flush leaves (Fig. 3). The emergence of second-flush leaves of F. crenata seedlings depends mainly on assimilation products from first-flush leaves in the current year (Hashizume 1982). In the present study, the $A_{\text {growth }}$ of first-flush leaves under elevated $\mathrm{CO}_{2}+\mathrm{O}_{3}$ treatment increased earlier and was approximately twice as high in third WAE as compared to the $A_{\text {growth }}$ in the elevated $\mathrm{CO}_{2}$ treatment, although this difference of $A_{\text {growth }}$ was not significant because of the large variation (Fig. 3). This early increase of $A_{\text {growth }}$ of first-flush leaves would thus contribute to the marked increase in the emergence of second-flush leaves.

Because a relatively high correlation between $G_{\mathrm{s}}$ and $A_{\text {growth }}$ in the first through fourth WAE was found under elevated $\mathrm{CO}_{2}+\mathrm{O}_{3}$ treatment, the increased stomatal opening would lead to an increase of $A_{\text {growh }}$ to some extent (Figs. 4 and 
5). However, the $A_{\text {growth }}$ reached the maximum value one week earlier than $\operatorname{did} G_{s}$. On the other hand, $\mathrm{CE}$ under elevated $\mathrm{CO}_{2}+\mathrm{O}_{3}$ treatment was higher than that under elevated $\mathrm{CO}_{2}$ treatment in the second and third WAE (Fig. 4). Therefore, we consider that the increase in $\mathrm{CO}_{2}$ fixation activity in the Calvin cycle was the main reason for the early increase of $A_{\text {growth }}$ under elevated $\mathrm{CO}_{2}+\mathrm{O}_{3}$ treatment. It has been observed that a relatively low concentration of $\mathrm{O}_{3}$ temporarily increased Rubisco quantity in the leaves of Betula pendula and F. sylvatica (Lütz et al. 2000; Pääkkönen et al. 1996). This is considered to be one of the compensation responses to $\mathrm{O}_{3}$ exposure. More carbon would be needed for an extended compensation response (Fuhrer and Booker 2003). In the present study, the possibility exists that the compensative response of $F$. crenata seedlings to $\mathrm{O}_{3}$ was stimulated under elevated $\left[\mathrm{CO}_{2}\right]$ due to the abundant carbon resource.

The timing of the decrease in $C E$ under the elevated $\mathrm{CO}_{2}+\mathrm{O}_{3}$ treatment was later than in the elevated $\mathrm{CO}_{2}$ treatment (Fig. 3). This result suggests that a relatively high level of $\mathrm{CO}_{2}$ fixation activity in the Calvin cycle was maintained under $\mathrm{CO}_{2}+\mathrm{O}_{3}$ treatment and contributed to the stimulation of dry matter growth in the seedlings through the increase of NAR.

Matsumura et al. (2005) reported that the amelioration of adverse $\mathrm{O}_{3}$ effects under elevated $\left[\mathrm{CO}_{2}\right]$ was not observed in $\mathrm{F}$. crenata seedlings from the open-top chamber experiment; this differs from the result of our study. We maintained $\mathrm{O}_{3}$ exposure for $6 \mathrm{~h}$ per day, 3 days per week, whereas the $F$. crenata seedlings of Matsumura et al. (2005) were exposed to $\mathrm{O}_{3}$ at 1.5 times ambient concentration for $24 \mathrm{~h}$ per day everyday. This difference in $\mathrm{O}_{3}$ exposure regime could be a reason for the differing results between the studies. Specifically, the 
absence of $\mathrm{O}_{3}$ exposure at night time in the present study may be an important factor since night is a time for recovery from $\mathrm{O}_{3}$ injury (De Temmerman et al. 2002). Moreover, Matyssek et al. (1995) reported that the level of reduction in whole-plant growth of $B$. pendula cuttings produced by night time exposure to $\mathrm{O}_{3}$ was similar to the level produced by day time $\mathrm{O}_{3}$ exposure. Therefore, the seedlings in the present study would recover more and stimulate the compensative response to adverse $\mathrm{O}_{3}$ effects during the night under elevated $\left[\mathrm{CO}_{2}\right]$ as compared to the results reported by Matsumura et al. (2005). On the other hand, there is a possibility that the provenance of $F$. crenata seedlings is also an important factor that may have induced different responses to $\mathrm{O}_{3}$ under elevated $\left[\mathrm{CO}_{2}\right]$ in the two studies. The provenance of the seedlings used in our study and those of Matsumura et al. (2005) were Toyama (Hokuriku region) and Hokkaido, respectively. Although it is thought that the $F$. crenata in the two regions are genetically similar (Koike et al. 1998; Tomaru et al. 1997), the exposure level of $\mathrm{O}_{3}$ in Toyama is relatively high as compared to the other regions in Japan, while relatively low levels of $\mathrm{O}_{3}$ exposure have been observed in Hokkaido (Kohno et al 2005). Paludan-Müller et al. (1999) reported that the $\mathrm{O}_{3}$ tolerance of $F$. sylvatica seedlings from southeast European provenances was higher than that of F. sylvatica seedlings from northwest European provenances. In that report, the authors speculated that the conditions of high $\mathrm{O}_{3}$ exposure of the southeast European provenances conferred an $\mathrm{O}_{3}$-tolerance on $F$. sylvatica seedlings. Molinier et al. (2006) indicated that genomic changes in response to environmental stresses could be inherited by successive generations. Therefore, there is a possibility that $F$. crenata seedlings used in the present study have high 
congenital compensative capacity to $\mathrm{O}_{3}$ as compared to those used in the study by Matsumura et al. (2005).

In conclusion, our hypothesis is partly supported. Although the reduction in $\mathrm{O}_{3}$ uptake in leaves of $F$. crenata seedlings was indicated under elevated $\left[\mathrm{CO}_{2}\right]$, it cannot explain the growth stimulation in elevated $\mathrm{CO}_{2}+\mathrm{O}_{3}$ treatment. On the other hand, the compensative response to $\mathrm{O}_{3}$ (i.e., increase of second-flush leaves) was surprisingly stimulated under elevated $\left[\mathrm{CO}_{2}\right]$, which may be due to the early increase in the net photosynthetic rate of the first-flush leaves before the emergence of second-flush leaves. As a result, highest growth was observed under $\mathrm{CO}_{2}+\mathrm{O}_{3}$ treatment. Based on the results obtained from the present study, we conclude that when evaluating the effects of $\mathrm{O}_{3}$ on $\mathrm{F}$. crenata under elevated $\left[\mathrm{CO}_{2}\right]$, we must take into account changes in compensative capacity brought about not only by morphological traits but also by phenological traits and physiological functions such as photosynthesis.

\section{Acknowledgments}

This study was partly supported by a Grant-in-Aid from the Japan Society for the Promotion of Science through its Research Fellowships for Young Scientists program (to M. Watanabe), Scientific Research on Innovative Areas (to T. Koike and I. Terashima) and Basic Research B grant (to T. Koike and K. Harada). The experiments conducted in the present study comply with the current laws of Japan. 


\section{Reference}

ADORC (Acid deposition and oxidant research center) (2006) Tropospheric ozone a growing threat. ADORC, Niigata.

Ainsworth E, Rogers A (2007) The response of photosynthesis and stomatal conductance to rising $\left[\mathrm{CO}_{2}\right]$ : mechanisms and environmental interactions. Plant Cell Environ 30:258-270

Akimoto H (2003) Global air quality and pollution. Science 302:1716-1719

Barnes JD, Pfirrmann T, Steiner K, Lutz C, Busch U, Küchenhoff H, Payer H-D (1995) Effects of elevated $\mathrm{CO}_{2}$, elevated $\mathrm{O}_{3}$ and potassium deficiency on Norway spruce [Picea abies (L) Karst.]: seasonal changes in photosynthesis and non-structural carbohydrate content. Plant Cell Environ 18: 1345-1457

Brown KA, Roberts TM (1988) Effects ozone on foliar leaching in Norway Spruce (Picea abies L. Karst): Confounding factors due to $\mathrm{NO}_{\mathrm{x}}$ production during ozone generation. Environ Pollut 55:55-73

Centritto M, Lee HS, Jarvis PG (1999) Increased growth in elevated $\left[\mathrm{CO}_{2}\right]$ : an early, short-term response? Glob Change Biol 5:623-633

De Temmerman L, Vandermeiren K, D’Haese D, Bortier K, Asard H, Ceulemans R (2002) Ozone effects on trees, where uptake and detoxification meet. Dendrobiology 47:9-19.

Dutilleul P (1993) Spatial heterogeneity and the design of ecological field experiments. Ecology 74:1646-1658

Eguchi N, Karatsu K, Ueda T, Funada R, Takagi K, Hiura T, Sasa K, Koike T (2008) Photosynthetic responses of birch and alder saplings grown in a free air $\mathrm{CO}_{2}$ enrichment system in northern Japan. Trees 22:437-447 
Emberson LD, Wieser G, Ashmore MR (2000) Modelling of stomatal conductance and ozone flux of Norway spruce: comparison with field data. Environ Pollut 109:393-402

Farquhar GD, von Caemmerer S, Berry JA (1980) A biochemical model of photosynthetic $\mathrm{CO}_{2}$ assimilation in leaves of C3 species. Planta 149:78-90

Fuhrer J, Booker F (2003) Ecological issues related to ozone: agricultural issues. Environ Int 29:141-154

Grams TEE, Anegg S, Häberle K-H, Langebartels C, Matyssek R (1999) Interactions of chronic exposure to elevated $\mathrm{CO}_{2}$ and $\mathrm{O}_{3}$ levels in the photosynthetic light and dark reactions of European beech (Fagus sylvatica). New Phytol 144:95-107

Hashizume H (1982) The effect of light intensity on the growth and development of Fagus crenata seedlings. Bull Fac Agr Tottori Univ 34:82-88 (in Japanese with English summary)

Hashizume H, Yamamoto S (1975) Study on the formation process of beech forest (II) change in the characteristics of sapling by the difference of growth condition. Proceed 86th Con Jpn For Soc 228-229

Hunt R (1978) Growth analysis of individual plants. In: Plant growth analysis. Studies in Biology 96, Edward Arnold Limited, London: pp 8-25

Ishida M (2004) Planting Fagus crenata seedlings at the deforestation spots along Tateyama Alpine route and its results. J Jpn Soc Revege Tech 29:503-506 (in Japanese with English summary) 
Izuta T, Umemoto M, Horie K, Aoki M, Totsuka T (1996) Effects of ambient levels of ozone on growth, gas exchange rates and chlorophyll contents of Fagus crenata seedlings. J Jpn Soc Atmos Environ 31:95-105

Karnosky DE, Oksanen E, Dickson RE, Isebrands JG (2001) Impacts of interacting greenhouse gases on forest ecosystems. In: Karnosky DF, Scarascia-Mugnozza G, Geulemans R, Innes JL (eds) The impacts of carbon dioxide and other greenhouse gases on forest ecosystems. CABI Press, Wallingford UK: pp 253-267

Kikuzawa K (1983) Leaf survival of woody plant in deciduous broad-leaved forests. 1. Tall trees. Can J Bot 61:2133-2139

Kitao M, Koike T, Tobita H, Maruyama Y (2005) Elevated $\mathrm{CO}_{2}$ and limited nitrogen nutrition can restrict excitation energy dissipation in photosystem II of Japanese white birch (Betula platyphylla var. japonica) leaves. Physiol Plant 125:64-73.

Kitao M, Löw M, Heerdt C, Grams TEE, Häberle K-H, Matyssek R (2009) Effects of chronic elevated ozone exposure on gas exchange responses of adult beech trees (Fagus sylvatica) as related to the within-canopy light gradient. Environ Pollut 157:537-544

Kohno Y., Matsumura H., Ishii T. and Izuta T., 2005. Establishing critical levels of air pollutants for protecting East Asian vegetation - A challenge. In: Omasa K., Nouchi I. and De Kok L.J. (eds), Plant responses to air pollution and global change, Springer-Verlag, Tokyo: pp 243-250 
Koike T, Kato S, Shimamoto Y, Kitamura K, Kawano S, Ueda K, Mikami T. (1998) Mitochondrial DNA variation follows a geographic pattern in Japanese beech species. Bot Acta 11:87-92

Koike T, Maruyama Y (1998) Comparative ecophysiology of the leaf photosynthetic traits in Japanese beech grown in provenances facing the Pacific Ocean and the Sea of Japan. J. Phytogeography Taxonomy 46:23-28 (in Japanese with English summary)

Kozovits AR (2003) Competitiveness of young beech (Fagus sylvatica) and spruce (Picea abies) trees under ambient and elevated $\mathrm{CO}_{2}$ and $\mathrm{O}_{3}$ regimes Ph.D. thesis, Technische Universität München

Kull O, Sober A, Coleman MD, Dickson RE, Isebrands JG, Gagnon Z, Karnosky DF (1996) Photosynthetic responses of aspen clones to simultaneous exposures of ozone and $\mathrm{CO}_{2}$. Can J For Res 26:639-648

Kume A., Numata S., Watanabe K., Honoki H., Nakajima H. and Ishida M. (2009) Influence of air pollution on the mountain forests along the Tateyama-Kurobe Alpine route. Ecol Res 24:821-830

Lambers H, Chapin III FS, Pons TL (2008) Plant physiological ecology, second edition. Springer, New York.

Landolt W, Günthardt-Goerg MS, Pfenninger I, Einig W, Hampp R, Maurer S, Matyssek R (1997) Effect of fertilization on ozone-induced changes in the metabolism of birch (Betula pendula) leaves. New Phytol 137:389-397

Lippert M, Steiner K, Payer H-D, Simons S, Langebartels C, Sandermann Jr H (1996) Assessing the impact of ozone on photosynthesis of European beech (Fagus sylvatica L.) in environmental chambers. Trees 10:268-275 
Lütz C, Anegg S, Gerant D, Alaoui-Sossé B, Gérard J, Dizengremel P (2000) Beech trees exposed to high $\mathrm{CO}_{2}$ and to simulated summer ozone levels: Effects on photosynthesis, chloroplast components and leaf enzyme activity. Physiol Plant 109:252-259

Manes F, Vitale M, Donato E, Paoletti E (1998) $\mathrm{O}_{3}$ and $\mathrm{O}_{3}+\mathrm{CO}_{2}$ effects on a mediterranean evergreen broadleaf tree, holm oak (Quercus ilex L.). Chemosphere 36:801-806

Matsumura H, Mikami C, Sakai Y, Murayama K, Izuta T, Yonekura T, Miwa M, Kohno Y (2005) Impacts of elevated $\mathrm{O}_{3}$ and/or $\mathrm{CO}_{2}$ on growth of Betula platyphylla, Betula ermanii, Fagus crenata, Pinus densiflora and Cryptomeria japonica seedlings. J Agric Meteorol 60:1121-1124

Matyssek R, Gunthardt-Goerg MS, Saurer M, Keller T (1995) Night-time exposure to ozone reduces whole-plant production in Betula pendula. Tree Physiol 15:159-165

Matyssek R, Sandermann H (2003) Impact of ozone on trees: an ecophysiological perspective. In: Esser K, Lüttge U, Beyschlag W, Hellwig F (eds) Progress in Botany 64. Springer-Verlage, Berlin Heidelberg: pp 349-404

McKee IF, Farage PK, Long SP (1995) The interactive effects of elevated $\mathrm{CO}_{2}$ and $\mathrm{O}_{3}$ concentration on photosynthesis in spring wheat. Photosynth Res 45:111-119

Miao SL, Wayne PM, Bazzaz FA (1992) Elevated $\mathrm{CO}_{2}$ differentially alters the responses of coocurring birch and maple seedlings to a moisture gradient. Oecologia 90:300-304 
Molinier J, Ries G, Zipfel C, Hohn B (2006) Transgeneration memory of stress in plants. Nature 442:1046-1049

Murai H., Yamatani K., Kataoka Y. and Yui M., 1991. Natural environment and its conservation on Buna (Fagus crenata) forest. Soft science, Inc., Tokyo

Nakashizuka T, Iida S (1995) Composition, dynamics and disturbance regime of temperate deciduous forests in Monsoon Asia. Vegetatio 121:23-30

Nakashizuka T (2004) Story of forest trees and Japan. Tokai University Press, Hatano (in Japanese).

Network Center for EANET, 2007. Data report 2006, Network Center for EANET. http://www.eanet.cc/product.html Accessed 19 June 2009.

Ohara T, Sakata T, 2003. Long-term variation of photochemical oxidants over Japan. J Jpn Soc Atmos Environ 38:47-54 (in Japanese with English summary).

Oksanen E, Saleen A (1999) Ozone exposure results in various carry-over effects and prolonged reduction in biomass in birch (Betula pendula Roth). Plant Cell Environ 22:1401-1411

Pääkkönen E, Vahala J, Holopainen T, Karjalainen R, Kärenlampi L (1996) Growth responses and related biochemical and ultrastructural changes of the photosynthetic apparatus in birch (Betula pendula) saplings exposed to low concentrations of ozone. Tree Physiol 16:597-605

Paludan-Müller G, Saxe H, Leverenz JW (1999) Responses to ozone in 12 provenances of European beech (Fagus sylvatica): genotypic variation and chamber effects on photosynthesis and dry-matter partitioning. New Phytol $144: 261-273$ 
Pell EJ, Temple PJ, Friend AL, Mooney HA, Winner WE (1994) Compensation as a plant response to ozone and associated stresses: an analysis of ROPIS experiments. J Environ Qual 23:429-436

Peters R (1997) Beech forests. Kluwer Academic Publishers, Dordrecht

Pettersson R, Mcdonald AJS (1992) Effects of elevated carbon dioxide concentration on photosynthesis and growth of small birch plants (Betula pendula Roth.) at optimal nutrition. Plant Cell Environ 15:911-919

Pearson M, Mansfield TA (1993) Interacting effects of ozone and water stress on the stomatal resistance of Beech (Fagus sylvatica L.) New Phytol $123: 351-358$

Potvin C, Tardif S (1988) Sources of variability and experimental designs in growth chambers. Funct Ecol 2:123-130

Saxe H, Ellsworth DS, Health J (1998) Tree and forest functioning in an enriched $\mathrm{CO}_{2}$ atmosphere. New Phytol 139:395-436

Sharkey TD (1985) Photosynthesis in intact leaves of C3 plants: Physics, physiology and rate limitations. Bot Rev 51:53-105

Shimizu H, Feng YW (2007) Ozone and/or water stresses could have influenced the Betula ermanii Cham. forest decline observed at Oku-Nikko, Japan. Environ Monit Assess 128:109-119

Takeda M, Aihara K (2007) Effects of ambient ozone concentrations on Beech (Fagus crenata) seedlings in the Tanzawa Mountains, Kanagawa Prefecture, Japan. J Jpn Soc Atmos Environ 42:107-117 (in Japanese with English summary). 
Terazawa K, Koyama H (2008) Applied ecology for restoration of beech forests. Bun-ichi Sogo Shuppan Co., Tokyo (in Japanese)

Tomaru N, Mitsutsuji T, Takahashi M, Tsumura Y, Uchida K, Ohba K (1997) Genetic diversity in Fagus crenata (Japanese beech): influence of the distributional shift during the late-Quaternary. Heredity 78:241-251

Volin JC, Reich PB (1996) The interaction of elevated $\mathrm{CO}_{2}$ and $\mathrm{O}_{3}$ on growth, photosynthesis and respiration of three perennial species grown in low and high nitrogen. Physiol Plant 97:674-684

Volin JC, Reich PB, Givnish TJ (1998) Elevated carbon dioxide ameliorates the effects of ozone on photosynthesis and growth: species respond similarly regardless of photosynthetic pathway or plant functional group. New Phytol $138: 315-325$

von Caemmerer S, Farquhar GD (1981) Some relationships between the biochemistry of photosynthesis and the gas exchange of leaves. Planta $153: 376-387$

Wakamatsu S, Uno I, Ohara T (1998) Springtime photochemical air pollution in Osaka: Field observation. J Appl Meteorol 37:1100-1106

Watanabe, M., Yonekura, T., Honda, Y., Yoshidome, M., Nakaji, T. and Izuta, T. (2005) Effects of ozone and soil water stress, singly and in combination, on leaf antioxidative systems of Fagus crenata seedlings. J Agric Meteorol 60:1105-1108.

Yamaguchi M., Watanabe M., Iwasaki M., Tabe C., Matsumura H., Kohno Y. and Izuta, T., 2007. Growth and photosynthetic responses of Fagus crenata seedlings to $\mathrm{O}_{3}$ under different nitrogen loads. Trees 21:707-718. 
Yonekura T, Honda Y, Oksanen E, Yoshidome M, Watanabe M, Funada R, Koike T, Izuta T (2001) The influences of ozone and soil water stress, singly and in combination, on leaf gas exchange rates, leaf ultrastructural characteristics and annual ring width of Fagus crenata seedlings. J Jpn Soc Atmos Environ 36:333-351

Yoshikado H., 2004. One possible factor causing recent trend of photochemical oxidants. J Jpn Soc Atmos Environ 39:188-199 (in Japanese with English summary)

\section{Figure captions}

Fig. 1 Leaf area of F. crenata seedlings at the end of the experimental period. Each value is the mean of five determinations. The vertical bar indicates standard deviation. Two-way ANOVA: ${ }^{* *} p<0.01$; ${ }^{* * *} p<0.001$; ns not significant. Values with different letters are significantly different, with a $p<0.05$

Fig. 2 Relative growth rate (RGR), net assimilation rate (NAR) and leaf area ratio (LAR) of F. crenata seedlings during 18 weeks of $\mathrm{O}_{3}$ exposure. Values are shown relative to the control treatment. The absolute values of RGR, NAR, and LAR in the control treatment were $1.36 \times 10^{-2} \mathrm{~g} \mathrm{~g}^{-1}$ day $^{-1}, 5.22 \times 10^{-4} \mathrm{~g} \mathrm{~cm}^{-2} \mathrm{day}^{-1}$, and $25.98 \mathrm{~cm}^{2} \mathrm{~g}^{-1}$, respectively. Each value is the mean of five determinations 
Fig. 3 Specific leaf area (SLA) and leaf mass ratio (LMR) of F. crenata seedlings at the end of the experimental period. Each value is the mean of five determinations, The vertical bar indicates standard deviation. Two-way ANOVA: * $p<0.05$; ns not significant. Values with different letters are significantly different, with a $p<0.05$

Fig. 4 Net photosynthetic rate at growing $\mathrm{CO}_{2}$ concentrations ( $A_{\text {growth }}$ a, b), stomatal conductance (c, d), carboxylation efficiency (e, f), and maximum net photosynthetic rate $\left(A_{\max }, \mathrm{g}, \mathrm{h}\right)$ in the first-flush leaves of $F$. crenata seedlings. Each value is the mean of three determinations. The vertical bar indicates standard deviation. Vertical dashed lines in (a) and (b) indicate the emergence time of second-flush leaves

Fig. 5 Relationship between stomatal conductance and net photosynthetic rate at growing $\mathrm{CO}_{2}$ concentration ( $\left.A_{\text {growth}}\right)$ in the first-flush leaves of $F$. crenata seedlings. Solid and dashed lines indicate the regression line for the elevated $\mathrm{CO}_{2}$ and elevated $\mathrm{CO}_{2}+\mathrm{O}_{3}$ treatments, respectively. WAE $=$ Week after the initiation of $\mathrm{O}_{3}$ exposure 


\section{Table 1}

Table 1 Dry mass of plant organs and the ratio of above-ground dry mass to below-ground dry mass (T/R ratio) of $F$. crenata seedlings at the end of the experimental period

\begin{tabular}{|c|c|c|c|c|c|c|c|c|c|}
\hline \multirow[b]{2}{*}{ Treatment } & \multicolumn{8}{|l|}{ Dry mass } & \multirow[b]{2}{*}{$\begin{array}{l}\mathrm{T} / \mathrm{R} \\
\text { ratio }\end{array}$} \\
\hline & $\begin{array}{l}\text { 1st flush } \\
\text { leaves }\end{array}$ & $\begin{array}{l}\text { 2nd flush } \\
\text { leaves }\end{array}$ & Bud & Branch & Stem & $\begin{array}{l}\text { Fine } \\
\text { root }\end{array}$ & $\begin{array}{c}\text { Coarse } \\
\text { root }\end{array}$ & Whole-plant & \\
\hline Control & 0.361 & 0.770 a & 0.388 & $0.720 \mathrm{ab}$ & 2.064 a & 1.708 & $2.136 \mathrm{a}$ & 8.146 a & 1.078 \\
\hline Elevated $\mathrm{O}_{3}$ & 0.396 & 1.079 a & 0.339 & 0.603 a & $1.683 \mathrm{a}$ & 1.859 & $1.910 \mathrm{a}$ & 7.820 a & 1.138 \\
\hline Elevated $\mathrm{CO}_{2}$ & 0.521 & 1.295 a & 0.618 & $1.404 \mathrm{~b}$ & 2.266 a & 2.880 & $3.531 \mathrm{~b}$ & $12.505 \mathrm{~b}$ & 0.978 \\
\hline Elevated $\mathrm{O}_{3}+\mathrm{CO}_{2}$ & 0.582 & $3.757 \mathrm{~b}$ & 0.508 & $3.130 \mathrm{c}$ & $3.338 \mathrm{~b}$ & 4.562 & 4.677 c & 20.553 c & 1.258 \\
\hline \multirow[t]{3}{*}{ ANOVA } & ns & $* * *$ & ns & $* * *$ & ns & * & $*$ & $* * *$ & ns \\
\hline & $* *$ & $* * *$ & $* *$ & $* * *$ & $* * *$ & $* * *$ & $* * *$ & $* * *$ & ns \\
\hline & $\mathrm{ns}$ & $* *$ & ns & $* * *$ & $* *$ & ns & $* *$ & $* * *$ & ns \\
\hline
\end{tabular}

Each value is the mean of 5 determinations.

Two-way ANOVA: * $p<0.05$; ** $p<0.01$; ** $p<0.001$; ns not significant.

Within the same parameter, values with different letters are significantly different, with a $p<0.05$. 


\section{Fig. 1}

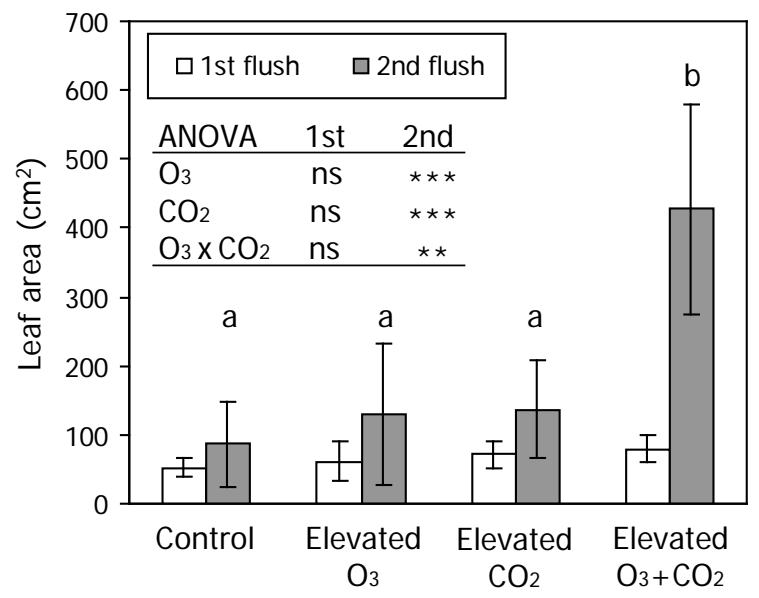




\section{Fig. 2}

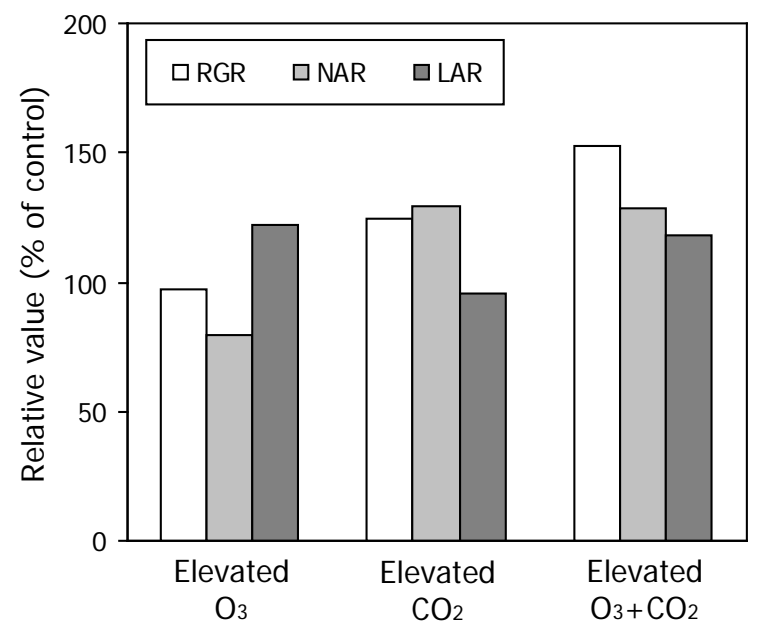




\section{Fig. 3}
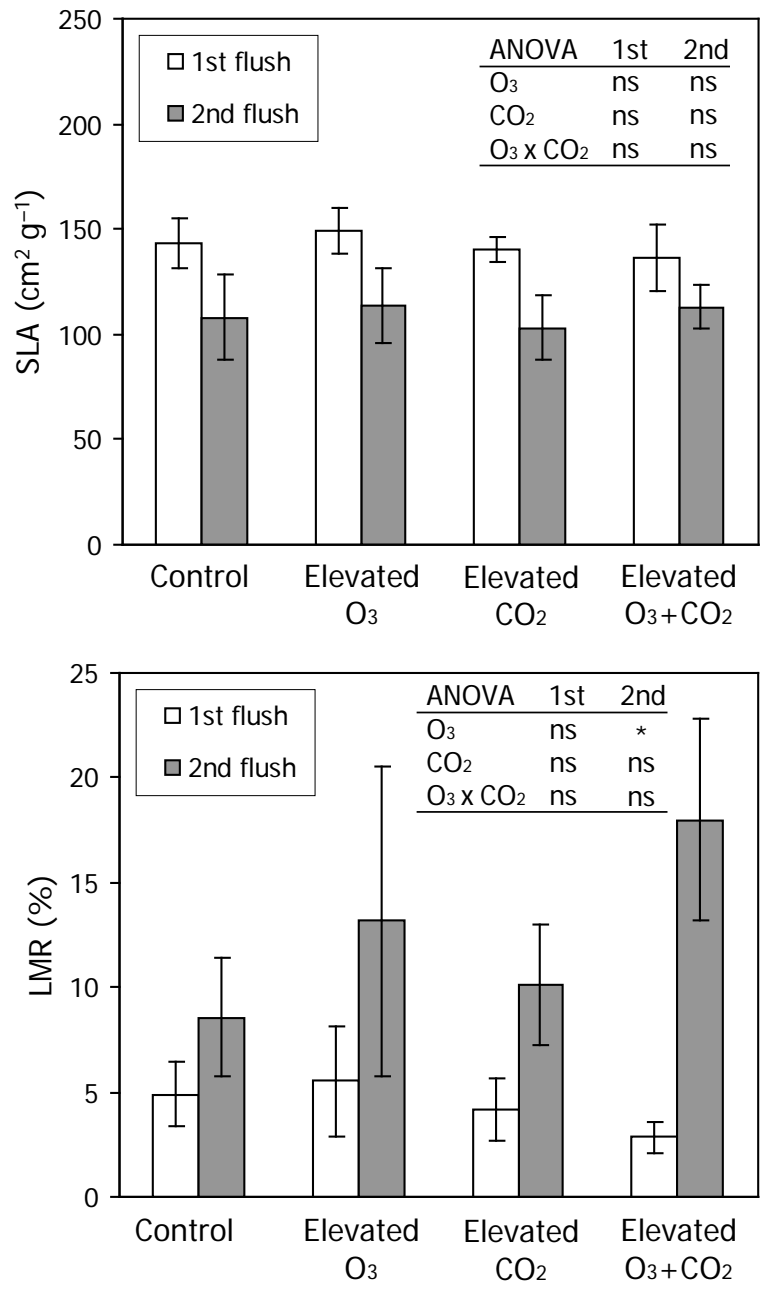


\section{Fig. 4}
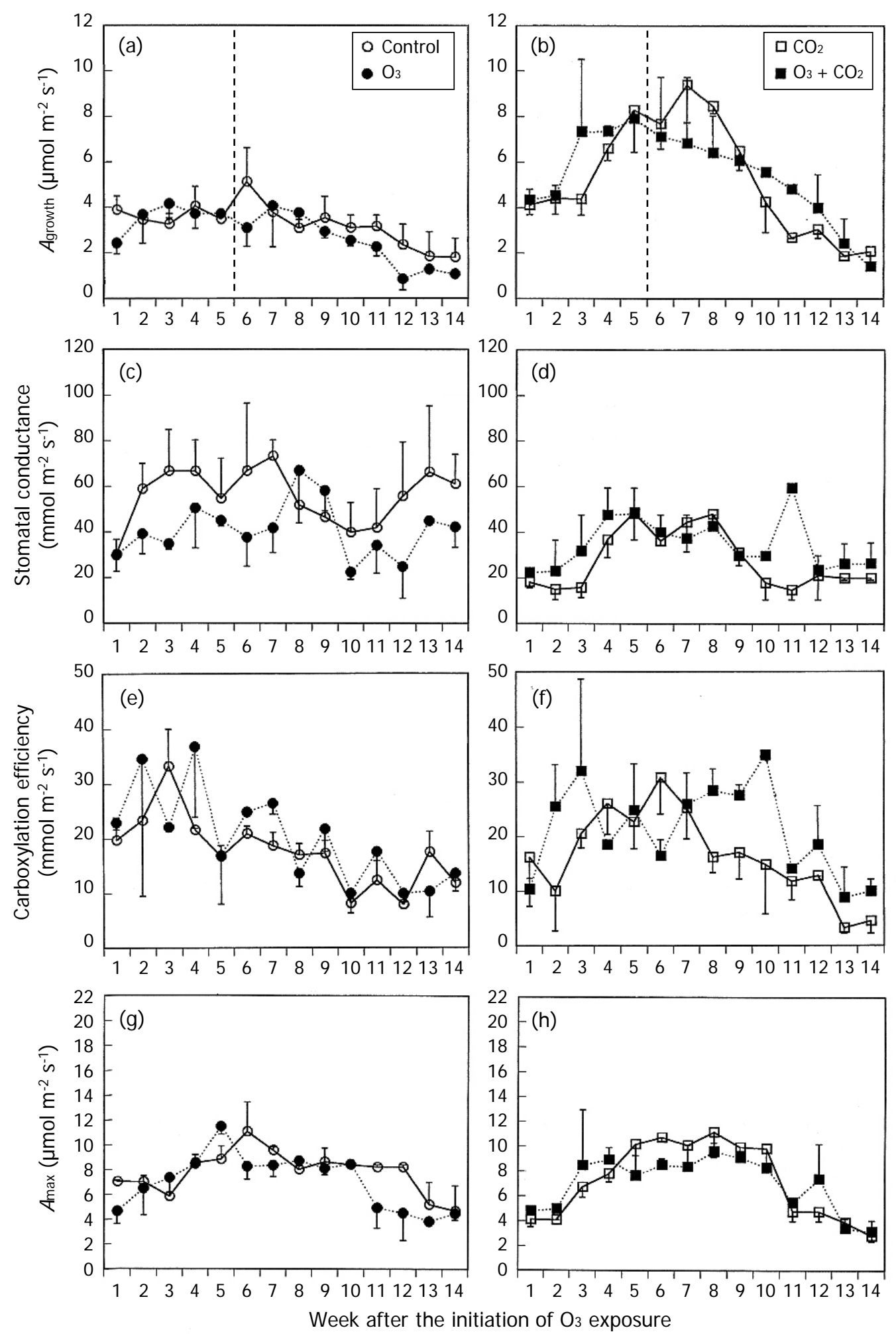


\section{Fig. 5}

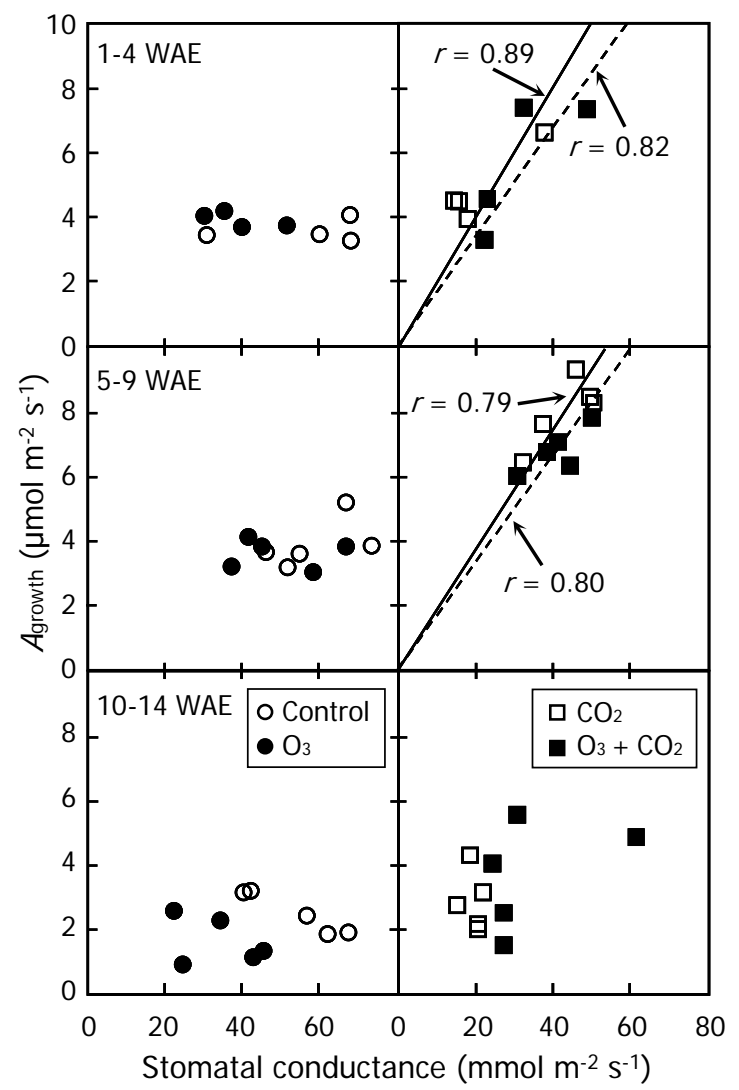

